\title{
Social work during the COVID-19 pandemic. Administrative and personal response to new challenges
}

\author{
Claudia Bacter ${ }^{1 *}$, Sorana Săveanu ${ }^{1}$, Cristiana Marc ${ }^{1}$ \\ ${ }^{1}$ University of Oradea, 1 Universității Street, Oradea, 410087, Bihor, Romania.
}

KEYWORDS

COVID-19 pandemic

Social services

Administrative changes

Communication

\section{ABSTRACT}

The crisis generated by the COVID-19 pandemic implied specific intervention measures in all areas worldwide. Social workers from the social care system and health services, along with other specialists, have played an extremely important role in providing support to vulnerable groups, in order to manage social and psychological issues that have emerged in this period. This paper presents the results of a study involving 94 social workers from Romania. The aim of the research was to identify the main changes in the activity of social workers from public and private social services during pandemic, a period characterized by restrictive measures in order to limit the transmission of the virus. The paper focuses on vulnerabilities and challenges imposed by these changes in order to continue to provide social services for those in need. Recommendations on social policies are outlined based on the lessons learned in this period. The results show that communication and the maintenance of the relationship with beneficiaries are the parts where most changes occurred. The limitation of direct contacts has led to a decrease in field activity, online work, increased workload, or changes in working schedule, and also sometimes (mainly in public institutions) increased bureaucracy. Based on the results of the study, some recommendations for policy makers are identified, taking advantage of the lessons from this period of crisis: the need for the authorities to prioritize the allocated resources and to impose stricter rules to follow, provide funding for specific resources, intensifying the collaboration between all social actors involved, developing and implementing unitary intervention models, greater interest and understanding from authorities and responsiveness to new intervention methods, maintaining the online activity where the situation allows it in order to reduce bureaucracy in public institutions.

*Contact address: claudianbacter@gmail.com (C. Bacter) 


\section{Introduction}

The restrictive measures adopted by each country as a necessary condition for the limitation of the community transmission of the SARS-CoV-2 virus have led to global changes in professional activity in most areas, with implications for all social actors involved.

The COVID-19 pandemic pressures the provision of social services. Beneficiaries or risk groups such as children, the elderly, people with disabilities, those in social-health centers and in hospitals etc., represent very vulnerable categories that need to deal with the fight against the virus. Therefore, social workers have an important role in preventing and controlling the spread of coronavirus. Pursuing the provision of quality social services and protecting their own health and the health of their clients, social workers experience new situations in which daily activity is linked to compliance with the authorities' requirements regarding social distancing, technology-mediated communication, encountering blockages and finding innovative solutions. The complexity of the social worker profession, the need for communication with clients, facing difficult situations imposed by the global crisis, shape the response of social workers to pandemic challenges and highlight their key-role in meeting social and psychological needs as frontline staff (Golightley and Holloway 2020; Redondo-Sama et al. 2020; Sukmana and Abidin 2020).

During the pandemic, the activity of social workers was and still is affected by social distancing measures, limited access to resources and permanent changes in the directions of intervention. The significant efforts of social workers aim to adapt to the additional needs of individuals and to find innovative ways to provide social services. The conclusions of an international study conducted during this period highlights the fact that 'The pandemic raises many political, professional and personal challenges for policymakers, social workers, and people who use social work services' (Banks et al. 2020b, 570). 
Risk exposure, additional workloads, and worries because of the new rules applied in daily activity, limited resources, skills and experiences, can all generate stress.

The paper draws attention to the changes in social work activity during the pandemic and the impact of these changes on how social services continued to be provided for those in need. It also brings focus on things that have changed, challenges posed by the new rules and working conditions, what needs to be changed and how public authorities should act in order to promote and provide effective intervention measures in a time of crisis. Recommendations on social policies can be outlined starting from the lessons and challenges of this period.

\section{Context. Social services during the pandemic in Romania}

Studies reveal several problems faced by social workers from Romania, these problems being identified in the period before the COVID 19 pandemic. Main problems refer to insufficient human resources and the employment of persons without special training in the field, the great amount of work tasks, the large number of cases and the increase of their complexity, a low level of understanding from heads of institutions and colleagues with other qualifications regarding their clients priority needs (focus on costs and less focus on providing real support), bureaucracy, too many forms to complete, insufficient material and logistics resources, the lack of adequate workspace, difficulties in cooperation between institutions and also within the same institution, lack of uniform work methodologies, concerns regarding personal safety at work, reduced access to professional training, emotional and mental stress, lack of professional supervision, job insecurity (Lazăr et al. 2020; Bacter and Marc 2017; Lazăr, Dégi, and Iovu 2016; Marc and Oșvat 2013). To all of these problems, we can add the legislative changes and the fact that a part of the legislation and methodologies allows for interpretations on how procedures can be applied in fieldwork. Social workers note that these are all obstacles to an effective intervention. Moreover, the unequal distribution of 
social services in communities increase social inequalities, making certain categories of the population more vulnerable (Lazăr et al. 2019).

Any crisis situation highlights the weaknesses and brings the vulnerabilities and the functioning instabilities to the surface, at a personal and also at the group, community and society level. However, strengths and several positive aspects can also be brought to attention and available resources can be (re)discovered.

The activity of social workers suffered substantial changes because of the restrictions imposed in order to limit the transmission of the SARS-CoV-2 virus. All restrictive measures were necessary and beneficial for the safety of professionals and clients. The implementation of social distance measures generated limitations of the social workers' activity, who usually work directly with socially disadvantaged groups and with individuals who do not have many resources.

In Romania, the state of emergency was established for a 30-day period on March 16, 2020, by Decree no. 195/ 2020 and was extended by another 30 days by Decree no. 240/2020. According to article 10, line 1 of the Military Ordinance no. 8/2020, during the state of emergency, a preventive isolation measure was imposed at the workplace or in special areas dedicated to employees from residential social centers. On May 15, 2020, the National Committee for Emergency Situations declared the state of alert, according to Decision no. 24/14.5.2020. The state of alert was subsequently extended for additional periods of 30 days until present (august 2021).

In order to maintain the health and safety of beneficiaries and employees in social services, the Ministry of Labor and Social Protection and its subordinate institutions developed instructions and recommendations such as: replacing monitoring visits with monitoring by phone or digital technology, online (by e-mail), when possible; phone and online communication with colleagues, members of integrated teams, other local professionals, families of beneficiaries, temporarily unavailable staff, authorities etc.; adopting a flexible work program/establishing individualized work programs; hiring additional staff without competition; 
suspend some social services (family separation prevention services, day centers); identify volunteers to support staff; identification, with priority, of the families/relatives who can take their beneficiaries at home during the state of emergency. The recommendations also emphasize that, in this context, the need for specific training and supervision is imperative for social service employees, in order to provide psychosocial support to beneficiaries (Ministry of Labor and Social Protection 2020; ANDPDCA - National Authority for the Rights of Persons with Disabilities, Children and Adoptions 2020).

The National College of Social Workers in Romania (2020) developed sectorial recommendations that include: making the work schedule and work space more flexible, working from home, when possible, limit as much as possible the access of the population in the offices of the institution, limit the field activity and use alternative solutions such as phone calls and video equipment, have documents sent by e-mail, WhatsApp and so on (National College of Social Workers in Romania 2020). The recommendations of the Ministry of Labor and Social Protection ANDPDCA (2020) also aimed to establish updated procedures to regulate access to centers for residents, staff, volunteers and representatives of the authorities, 14-day isolation upon admission to the center, depending on the epidemiological assessment, interruption of the access of new beneficiaries during the state of emergency, providing detailed procedures for various activities (collection of medical waste, special access and exit routes for staff, the purchase of necessary materials, post office services, compliance with the rules of hygiene and control of spreading diseases, keeping social distance).

\section{The impact of pandemic on social services provision}

Regarding social service users, the pandemic determined the increase of their number (Redondo-Sama et al. 2020), the increase of stress caused by social isolation (Dominelli 2021), the increase of risk of depression and anxiety 
disorders (Banerjee 2020) and it revealed the inequity in accessing social services (Farkas and Romaniuk 2020; Mishna et al. 2020).

Changing the mechanisms of providing social services by shifting to online communication (video and phone calls, etc.) where this was possible, working from home and reducing some activities in institutions also implies the management of alternative methods and ensuring access to services for all disadvantaged groups given the necessary and available resources (Holliday et al. 2020; Walter-McCabe 2020).

A study of the International Federation of Social Workers conducted during 6th-18th of May 2020 with 607 subjects from 54 countries showed that the measures taken to control and prevent the spread of COVID-19 restricted the services and responsibilities usually performed by social workers and generated new needs and demands. Therefore, social workers faced the challenges and even sometimes could not switch to digital contact, had difficulties in building trust relationship from distance and keep confidentiality regarding customer requests and at the same time struggled with time and resource allocation. Some social workers reported the lack of guidance on how to act in these new conditions, some of them revealed indistinguishable barriers between professional and personal life, dealing with several negative emotions (helplessness, anger, fear, sadness, disappointment, etc.), stress and exhaustion (Banks et al., 2020a). There are other studies that also reveal the psychological impact of the pandemic on frontline staff manifested by anxiety and increased stress (Holliday et al. 2020; Dominelli 2021; Cole et al. 2020; Inchausti et al. 2020).

The COVID-19 pandemic led to the emergence of new categories of vulnerable people (such as persons affected by unemployment), but also to the increase of some of the existing social problems: the rise of the number of abandoned children, a higher number of neglected elderly people and persons with disabilities, domestic violence, stress, anxiety and the need to adapt interventions in crises situations through the use of new work procedures (Cook and Zschomler 2020; Dominelli 2021; Quality of Life Research Institute 2020; Sukmana and Abidin 2020). Redondo-Sama et al. (2020) propose the 
development of solidarity networks between civil society, organizations and employees in this field for a better management of a crisis situation like this one.

Studies reveal that the use of electronic communication channels between social workers and service users raised some ethical dilemmas related to social inequalities ('digital divide'), confidentiality, dual relationships and boundary-crossing (Boddy and Dominelli 2017; Farkas and Romaniuk 2020; Dominelli 2021).

A study that analyzed the ethical challenges faced by social workers in different countries or regions during the pandemic (North America and Europe, Latin America, Africa and South Asia) highlighted that, despite the wide variation of social workers' roles and international practice, common ethical challenges involve respecting the rights and dignity of beneficiaries, the prioritization of limited resources, and ensuring or improving living conditions. In the same study, the authors were interested in observing whether there are differences in direct work with beneficiaries and services provided by public or private organizations. The limited resources in some communities, the lack of access to technology, which deepened the problems of vulnerable groups, were arguments that were the basis for the decision of social workers to continue their face-to-face work with beneficiaries or to reopen some services in compliance with physical distance measures (Banks et al. 2020b). Researches from the same field show that this need was also identified in other countries (Abrams and Dettlaff 2000; Dominelli et al. 2020; UNICEF 2020).

In Romania, the UNICEF Report from April 2020 regarding the assessment of the situation of children and families with a focus on vulnerable groups shows that the provision of social services was affected by measures taken by the authorities (especially day centers, care services at home, rehabilitation services for children with disabilities). Pre-existing problems in the system got even worse, such as insufficient staff in residential centres or specialized primary services, and other new problems appeared, such as less mobility and fieldwork, less direct social interactions, lack of necessary 
resources and protection equipment (UNICEF Romania 2020). The results of a study with 36 respondents identified several effects of the pandemic on social workers in Romania such as anxiety, confusion, anger, helplessness, concern for the health of families, customers, colleagues and the economic impact of the pandemic. Some advantages of working in this context refer to a better acquaintance with clients, better appreciation of activities, services and staff by the clients, better communication with clients, better teamwork (Runcan 2020).

\section{Social work during the COVID-19 pandemic. Study conducted among social workers from Romania}

\subsection{Research methodology}

\subsubsection{Aim and research objectives}

Our paper explores the main changes faced by social workers during the COVID-19 pandemic and the implications, vulnerabilities and challenges imposed by these rapid and unprecedented changes in daily routine activity in the field of social work. Our objectives aim at exploring the impact of the COVID-19 pandemic on ensuring the continuity of providing social services with focus on changes in work procedures and changes in the relations with beneficiaries and collaborators. The paper discusses the challenges posed by the new rules and the need to promote work procedures that bring beneficiaries to the forefront and raises awareness on the importance of communication with social service users. All recommendations come in the context of ensuring the sustainability of social work services.

Our study focuses on what has changed from the perspective of how public and private institutions provided social services during pandemic, what needs to be changed and challenged in order to properly respond to social needs of different vulnerable groups and also on how public authorities and policy makers should get involved in promoting effective intervention measures to minimize the effects of pandemic. 
To address the main problems faced by social workers during the COVID-19 pandemic and to identify systemic changes that affected their work we conducted an explorative research among social workers from Romania.

Data collection took place in the period between May 11 and May 29, 2020, i.e. the last week of lockdown and two weeks after. We developed a research instrument consisting of 38 questions. The research instrument was distributed online in different communication networks used by social workers (Google Form). At the end of the data collection period, we obtained 94 self-completed questionnaires. Research ethics were followed as the subject participated in the study voluntarily and the confidentiality of the data received was ensured.

\subsubsection{Sample description}

The final data set is based on answers received from 54 respondents from public institutions (57.4\%) and 40 respondents from the private sector (mainly NGOs) (42.6\%). Some analyses are presented in a comparative perspective, looking to focus on possible different results based on the two situations.

Most of our respondents are employed in executive positions (77 respondents), and only 15 of them have a position in the organization's management structure.

Our study included 81 female respondents (86.2\%) and 13 male respondents (13.8\%). This gender representation corresponds to how women are over-represented in this field.

The average age of our respondents is 39.7 years old (6.9 standard deviations), the youngest being 26 years old, and the oldest 56 years old.

Regarding the work environment, 73 of the respondents carry out their primary activity in the urban area, and 17 of them mainly have activities in rural areas. 


\subsection{Analysis and research results}

\subsubsection{Social Workers' activity. Changes and challenges}

Most of our respondents are experienced professionals in the social work field. 61 of them (64.8\%) have over 10 years of experience (of which 18 respondents have over 20 years of experience) and only 16 of them have less than 5 years of experience in the field. Most of the respondents with more experience in the field (over 10 years) are found in public institutions (42 of them are working in public administration), while those who are relatively new in the field (less than 5 years) are in private organizations (10 of the respondents are working in NGOs). Results are similar regarding the years spent in the current job: those respondents who have had the same job for a longer time (over 10 years) are employed mostly in public administration, while respondents who have the current job for less than 10 years (and especially for less than 5 years) are found in NGOs. A number of 33 respondents with over 10 years of experience in their current job are working in public institutions, while only 10 of those with this amount of experience are employed in private organizations. Results are consistent with those found in the research regarding the profile of social workers in Romania (Lazăr 2015) which shows that $3 / 4$ of social workers are employed in public institutions and 1 in 5 works in NGO sector. Those with less experience (beginners and practitioners) are employed mostly in NGOs. This is because public institutions are more present in communities as they provide services developed according to the strategies adopted at the national level compared to private organizations (Lazăr 2015).

The COVID-19 pandemic emergency caused several changes in social workers' activity. Changes are found in work tasks, work procedures, and also in bureaucratic work. Regardless of the nature of these changes, respondents still consider in a great amount that they receive support in order to be able to implement. 
Figure 1. Changes during the COVID-19 pandemic in work tasks, administrative work and work procedures

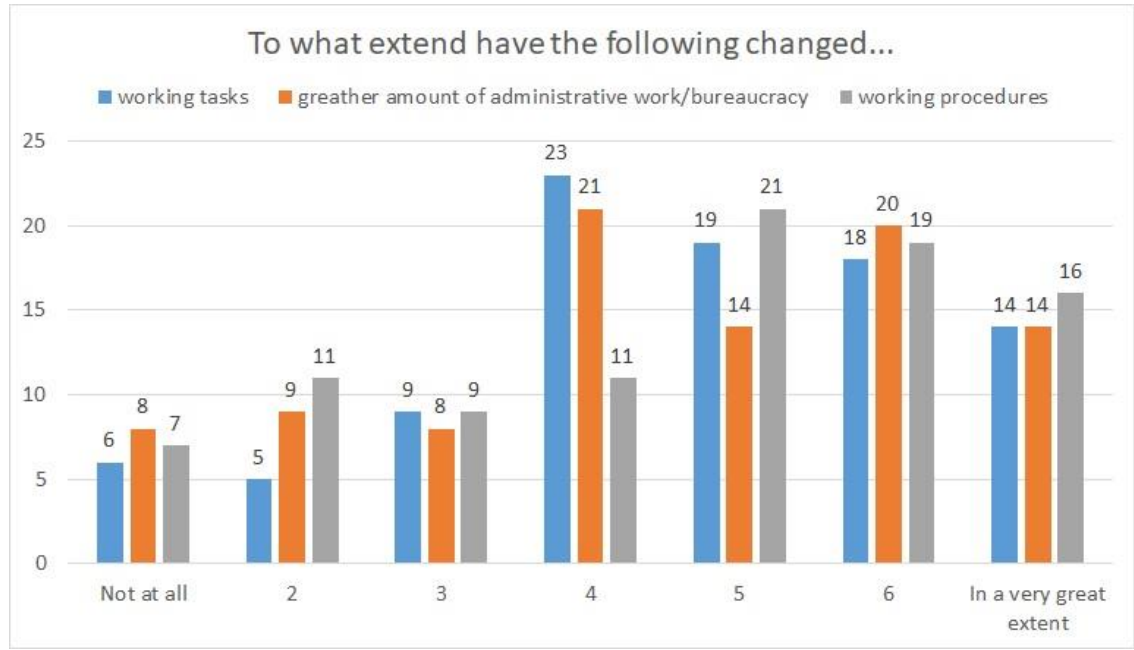

During the data collection period - including the last week of lockdown and the first two weeks after the lockdown - 56 social workers continued their work at the institution (in isolation or ordinary conditions), 23 of them worked from home and 15 of them were currently not working (technical unemployment, leave on request, other situation). Most of the respondents working in public administration continued their work at the institution (42 out of 54 from those in public institutions continued to go to work). Respondents from the private sector moved their work at home or even interrupted it. The relationship is significant for chi-square 17.7, $\mathrm{p}=0.000$.

Table 1. Work situation

\begin{tabular}{|c|c|c|c|}
\hline & $\begin{array}{c}\text { Public } \\
\text { institution }\end{array}$ & $\begin{array}{c}\text { Private } \\
\text { organization }\end{array}$ & Total \\
\hline working from home & 8 & 15 & 23 \\
\hline at the working place & 42 & 14 & 56 \\
\hline $\begin{array}{c}\text { currently not working (tech. } \\
\text { unemployment, leave, } \\
\text { other) }\end{array}$ & 4 & 11 & 15 \\
\hline Total & $\mathbf{5 4}$ & $\mathbf{4 0}$ & $\mathbf{9 4}$ \\
\hline
\end{tabular}


According to our data, there are no significant differences between public and private institutions regarding the changes of the work task, the changes in the amount of administrative work and the changes in the procedures because of the pandemic. Even though differences are not statistically significant, data show a greater number of changes in work tasks in private organizations compared to those in the public sector (on a scale from 1 to 7 , median is 5 with changes in private organizations and 4 with public administration). Regarding the increased amount of bureaucratic work, the situation is reversed: to a greater extent, social workers in the public sector consider that the bureaucratic work has increased compared to those from the private sector. This situation can be explained by referring to the measures established by the Ministry of Labour and the National Committee for Emergency Situations: procedures for access to residential centres for staff, volunteers, residents, government officials, ensuring the circuits for various activities, online communication with beneficiaries, colleagues and collaborators, limiting the access of the population in the offices of the institution, the necessity to adapt the practice through innovative solutions.

In our study, we asked the respondents to detail the key changes in work procedures. These changes correspond to the restrictions imposed by the emergency/alert situation (see Table 2). Social distancing measures had the greatest impact on social workers' activity. In this sense, a large part of the activity has moved remotely: activities held online or by phone. The working procedures were modified in order to respect social distance, and thus the number of direct contacts was strongly limited. This limitation meant reduced contact with beneficiaries and partners and less fieldwork, but these limitations did not imply less communication, as we will present in a section below. Providing social services for those in need continued during the lockdown period (some of our respondents even mention that nothing had changed in this period), however, activities that involved direct contact, such as group counselling or other joint activities, were redesigned so that the new rules could be followed. 
Some respondents mention that the amount of work has increased and their work schedule differed from the previous period. A large part of the administrative procedures has moved online: 'Lots of documents on WhatsApp', 'Remote monitoring', 'Indirect relationships with customers, collaborators stressed use of digital technology'. We emphasize in this sense that most of the times the activity was not interrupted, and it continued online. There are respondents who appreciate that by moving online they had to gain because sometimes communication became more intense. Anyhow, there are respondents who point out that these indirect contacts with the beneficiaries, no matter how frequent, cannot replace the real intervention that involves direct contact: 'Restrictive direct contact with beneficiaries', 'I can't keep in touch with the beneficiaries just by phone. They contact me for urgent problems'.

\subsubsection{Changes in the relationship with beneficiaries and collaborators}

The main changes imposed by the COVID-19 pandemic involved the reduction of direct contact with the beneficiaries, respectively with the collaborators and partners. We asked our respondents to detail how these relationships have changed.

The major change in the relationship with the beneficiaries refers to communication (see Table 3). There are social workers who claim that they faced real difficulties in maintaining contact with their beneficiaries and difficulties in offering support: 'It is difficult to keep in touch through social media networks with each beneficiary separately', 'Poor communication because there is no direct contact except in their crisis situations', 'During this period, communication is generally done through intermediaries', 'Beneficiaries no longer took part in therapies'. Some of our respondents mentioned that the communication moved online. Therefore, there was less direct contact and less social and emotional involvement: 'Activities with children are carried out only online, there is no longer the same visual, emotional, social impact', 'We had to provide services only remotely,' 'Less interaction,' 'Patients sometimes are more restrained.' There are social workers who consider that their relationship became closer by having more contact (direct or indirect) and more frequent communication 
with beneficiaries: 'My time is all theirs. I don't have a private life anymore!', 'We do several activities together: cleaning in common areas, cooking, household activities, sports, and recreational activities, role-playing games', 'Talking with the beneficiaries a lot!', 'The relationship with the beneficiaries was maintained, intensified by means of distance communication'. Some respondents consider that there were no significant changes in the relationship with beneficiaries.

The relationship with collaborators and partners changed in three ways: a) it changed little, just moved online or by phone; b) the collaboration was difficult, even interrupted, and c) better collaboration, more communication (see Table 4). Also, several respondents did not identify any perceptible changes in this relationship.

Regarding the changes in the relationship with collaborators, most of our respondents only mention moving online or by phone, without identifying a particular change: 'The collaboration has not changed. The method is unique, we collaborate more by phone, e-mail.', 'Mostly online,' 'I did not find any change, so far we have tried to solve the problems online.' On the other hand, there are social workers who point out rather serious problems regarding the development of the activities with the collaborators and partners: 'Not all institutions have given a prompt response online. Collaboration was more difficult with some institutions', 'Communication with institutions in the area is generally deficient, it is almost non-existent', 'There is no interaction', 'Mostly everyone is nervous and everyone tends to blame the others. Everybody is anxious. Some see dangers everywhere. Others see opportunities to attract all sorts of benefits. We are on the verge of paranoia. We become different people, many of us, or bring to the surface aspects of the personality we didn't know about until two months ago'. In some cases, these difficulties are imposed by the restriction of the activity (or its interruption) by the partners. On the contrary, there are organizations which improved their relationships with collaborators during the pandemic: 'We collaborate a lot using the internet', 'Greater trust and openness related to the exchange or transmission of information. Reduction, simplification of administrative procedures', 'The collaboration has intensified', 'More speed'. 


\subsubsection{Positive and negative aspects during the pandemic}

Without any doubt, the state of emergency and the state of alert period due to the pandemic were extremely difficult considering the changes that affected the professional activity in all fields and in the social work field as well. In our study we investigated the negative and the positive aspects which emerged in this period of crisis (see Table 5).

Most negative aspects refer to loosing direct contact, the uncertainty during these times, and stressful situations related to work: 'Discouragement and uncertainty about whether I will still have a job', 'Lack of direct interaction with beneficiaries and employees in social services', 'Uncertainty (how long will this period last?), blocking activities, isolation, stress and peer pressure', 'I can't do much of my social work activities, especially in counselling and offering support to beneficiaries)'. The elements related to personal characteristics that influenced social workers during this period were stress, mental tension and care for their own health and the health of others, while those related to organizational characteristics refer to uncertainty about the rules, not getting prompt information, lack of communication, pressure from the management.

Even though it may seem odd, some good things came out after the COVID-19 crisis. One of the major effects of the restrictions during the state of emergency was the shift of work to the online environment. In this sense, one of the positive implications refers to the digitalization of some activities: 'Digitalization facilitates certain aspects of work', 'Using the online more, I could send many docs to the institutions scanned by e-mail, no longer being necessary to go to the institution', 'Openness of institutions for online communication'. Other positive aspects mentioned by respondents refer to the closeness of people. Social workers reveal great solidarity in this period, more cohesion with colleagues or in the community, more implication: 'Collaborating with the community, they are much more involved', 'We got closer to each other', 'Greater openness and solidarity for those in suffering'. 


\subsubsection{Impact of the pandemic for future work. Some recommendations for social policies}

The pandemic will certainly leave its mark on how work is done in many areas. Regarding the provision of social services for vulnerable groups, social workers note the need to pay attention to the following issues, emphasizing the changes needed to be made in order to continue the activity: maintain hygiene measures and more involvement from authorities to distribute resources, greater involvement from all social actors in this field and greater collaboration, responsiveness to new intervention methods, changes in management (greater interest and understanding, new vision), flexibility at work and work schedule (See Table 6). However, there are respondents who do not consider that there is a need for concrete changes, and just want to return to work as it was before the pandemic. We do not know to what extent this statement means that they do not have proposals regarding the necessary changes in the public or private social systems, or their response is only shaped by the crisis context caused by pandemic. Although the study was conducted during the pandemic, these results must be correlated with those obtained in previous studies and observe which are those challenges and needs generated by the crisis situation compared to necessary changes that were reported even before the pandemic. One of the respondents expresses this situation very clearly: 'Changes should be made, but they are not related to the period we are going through'.

In our research we identified some common elements with those found in the studies presented in the theoretical background: the need for collaboration between all social actors in the field, higher level of understanding by the management representatives regarding the specific methods of intervention and the nature of social workers' activity and also the need for a new vision on the provision of social services. 


\subsubsection{Challenges for policy makers}

UNICEF (2020) proposed a series of measures to support governments, institutions and employees in the social field. Emphasis is placed on the importance of transmitting information about the evolution of the virus to workers, supervisors and decision-makers in order to take effective action, providing governments with funding and resources to support social services, collaboration of all actors involved, assessment of the ethical implications of interventions, assessment of the risks of transmission or exposure of staff to COVID-19 before deciding when direct contact with the beneficiaries is needed, the development and implementation of intervention models and training of social workers, supervision of their activity, the development and implementation of self-care plans. We note that many of these proposals are found among those made by social workers taking part in this study.

As the UNICEF report shows, the changes from this period represent challenges not only for social workers who need to continue their work, but also for policymakers who need to take the lessons learned in this period and make proposals for new measures in order to be able to ensure the sustainability of social services in crisis situations.

The most frequently mentioned measures that should be kept in the future refer to hygiene and other health protection measures (see Table 7). Social workers even recommend imposing stricter rules for compliance with these measures. Authorities should, on the one hand, take the responsibility to provide the necessary materials to ensure personal health safety at work, and on the other hand, authorities should impose mandatory rules at the work place: wearing gloves and masks, taking tests, etc.

Changes in social policies in the field must take into account the fact that certain activities were moved online and should be moved online in the future. Social workers notice the reduction in time of reaction in some situations and the fast transfer of information between institutions and within institutions, by using online documents and communication through online platforms. These types of changes in work procedures have a positive impact 
on the level of collaboration. Even if direct contact is reduced, the collaboration is more intense due to the frequency of online contacts. The use of online networks and communication channels make the work more operational and these measures must be maintained in the future.

Another recommendation refers to the flexibility of work and work schedule. Social workers consider that there are work tasks that they can perform from home. A flexible work schedule and periods of working from home would allow them to cover more tasks, especially those administrativebureaucratic ones (paper-work). Moreover, there are some social workers who mention that they do not have adequate conditions at work place (crowded offices, small spaces). These changes in the work schedule would also have a positive effect on the level of commitment and involvement.

In the context of suggestions for changes mentioned above, however, there are many social workers (26) who consider that none of the measures from this period should be maintained. This does not mean that these changes were not appropriate in a time of crisis, but the activity should return to 'normal', as it was carried out before.

\section{Discussion}

This study explores the changes in social workers' activities caused by the COVID-19 pandemic, focusing on work tasks, relationships with collaborators and beneficiaries, and on how social workers coped with these changes and with the entire crisis. The paper draws attention to lessons that were learned in this period and proposes recommendations on social policies based on the impact of changes during the pandemic.

The study aims to present some aspects of social workers' activity in public and private sectors. Results show certain particularities of the activities in the two sectors. Regarding how the activity is organized in public institutions, the vast majority of social workers included in the study continued their activities at the workplace, while many of those from NGOs worked from home or suspended their activity. 
A possible explanation for this situation would be the very nature of these activities alongside the fact that public institutions offer a wider range of social services and implicitly have a larger number of beneficiaries. The results of a study conducted in Romania also highlight the fact that social workers in public institutions feel the constant pressure of legislative regulations and have no decision-making power in terms of direct work intervention with service beneficiaries (Lazăr et al. 2019). The flexibility in deciding on the ways of intervention, the organization of the activity, specific to the NGOs, can explain the differences in the approach to the situation, as highlighted in the present study.

The pandemic has amplified old problems in social services, such as excessive bureaucracy in public institutions and difficulties in collaboration between and within institutions. Research data show changes in work tasks, which are greater in NGOs, as compared to public institutions, the social workers specifically referring to the need to prepare more documents and reports in the above-mentioned period.

Although, in general, the data got to show the adaptation of the social workers' activity to the new conditions, social distancing rules made their work difficult because of the lack of face-to-face interaction with beneficiaries. Interestingly, some social workers believe that communication with beneficiaries has improved while others appreciate that it became weaker. The lack of digital resources, information and skills required for many beneficiaries also contributed to the poor communication between social workers and beneficiaries.

As the data in this study show, the social service beneficiaries have become more vulnerable, more worried and online communication apparently failed to replace the specific intervention that involves a direct interaction, especially since social workers essentially deal with managing crises.

With regard to the management of the situation by social workers, these differences may also appear because of the particular way of adapting to the new requirements regarding the program, the work environment and 
technology. Situation management depended on individual resources, knowledge and skills, time management skills, and response to uncertainty, pressure and stress. The support of colleagues is noted as an important factor in adaptation; yet, there is no record whatsoever of managers' involvement in supporting social workers and moreover, one of the challenges for social policy identified in this study refers to a greater involvement and engagement from all social actors.

As a corollary for the experience of the pandemic period, a possible strategy for streamlining social services would be to use online services (if and when the situation allows) in order to reduce bureaucracy in public institutions.

\section{Study limitations}

In our study we used an explorative-descriptive approach. The study aimed to identify main changes that have emerged in a new situation, i.e., a crisis situation caused by pandemic. In this sense, it is necessary to deepen the results through further studies. The study captures the changes in terms of daily work, work procedures and relationship with beneficiaries and collaborators, but it is unable to identify the medium and the long-term impact of these changes.

Data collection began during the last week of lockdown and continued for another two subsequent weeks. The questionnaire was distributed online and was completed mostly during the last 4 days of the lockdown (81 of our respondents completed the questionnaire on May 11 - 14, 2020). In this sense, a limitation of the research refers to the fact that the sample is not a representative one. Data collection was based on the principle of opportunity, taking into account the availability of subjects and their spare time needed to answer all questions. Closely related to this aspect, another limitation refers to the fact that, by conducting the research online during lockdown, we may not have managed to include in the sample those social workers who suffered the most during this period due to the increased amount of work. It is possible 
that we weren't able to fully capture the perspective of social workers which were overloaded with work during this period due to the fact that they did not have the time available to participate in our study.

Another limitation of the research refers to the fact that data collection was online. In this sense, it is possible that those social workers who have reduced access to the Internet and to online communication devices were not included in the study. This kind of research should seek to cover all social services, in urban and also rural areas.

Our study is based on self-reported data. Like any other studies that are based on the answers received from subjects, we were not able to eliminate the biases due to this aspect and given the intensity of events in this period of crisis, it is possible that some aspects, especially those related to negative effects, may be exaggerated.

Most of the respondents are employed in executive positions; therefore they are less involved in decision making. Given that during this period the changes involved making decisions about work tasks and work procedures, it is important to describe the opinion of those in the management structure of organizations as well.

\section{Conclusions}

Going through a crisis never encountered before, social workers needed to adapt to the new conditions through changes in the ways they provided social services, with great implications on the relationships with colleagues, collaborators and beneficiaries. Besides program changes and new work tasks, the COVID-19 pandemic also brought along several issues, such as the stress and pressure regarding the health and the psychological well-being of social workers.

The most important changes in the professional activity mentioned by the subjects included in our study refer to limited direct contact with beneficiaries, colleagues and collaborators, switching to remote work (online or by phone), the increased amount of work, uncertainty about the future, 
worries about their own health and the health of others. All these changes represent real challenges for social workers to find innovative solutions to meet the needs of beneficiaries. Some services moved online; some activities got postponed or even cancelled, some of the collaborations were interrupted, and specialists had to come up with a prompt response to these new situations.

Both good self-care and organizational strategies are needed to reduce the pressure of new working conditions. Maintaining calm, teamwork support, solidarity and involvement seem to be key elements in managing the crisis. In order to support social workers and to improve communication with beneficiaries, the following measures are important: adequate workload, clear work procedures, discussions with colleagues and superiors, supervision, support groups, efficient time and stress management, healthy work-life balance.

The study reveals an interesting aspect regarding communication. It has changed in three directions: either it has moved online without encountering major changes, either it was intensified (improved) by increasing the number of online or phone contacts or directly with those who remained in institutions alongside with beneficiaries or communication has deteriorated (meaning less contact as a result of moving online).

The pandemic emphasizes the need to correctly identify existing needs and ensure adequate resources to adapt to the digitalization of social workers' activity and also provide social services in the new conditions. In this regard, UNICEF considers that in order to overcome the current crisis in the best way possible, the institutional capacity of the public sector who provides social services must be developed through additional staff, professionalization, and its proper endowment, establishing functional collaborations between relevant institutions at county and community levels; digitization, where it is possible; achieving, at the local level, the partnership with civil society (UNICEF Romania 2020).

Special attention must be focused on how alternative methods (digital technology) used in intervention can ensure the proper conduct of work with 
vulnerable categories, under professional values and principles so that their rights and the principle of equity in access to services are followed.

The most important aspects in this new context are represented by the improvements in communication channels with vulnerable groups and the design of the intervention according to the prioritization of social needs.

In order to successfully face the challenges and maintain the best practices in the field it is necessary to continuously inform and train social workers and also support them to develop new skills. Social workers should receive assistance from both professional associations and their employers.

From our perspective, the improvement of social policies should include the following aspects: maintaining hygiene measures and health protection measures, conducting an analysis of the possibility of working online regarding certain tasks, sending documents online, having a more flexible work schedule combined with work from home, more involvement and collaboration from all actors in the field, a change of vision regarding the collaboration and communication relationship with those in the management structure. In addition to these, special attention should also be paid to (public) health promotion programs through community education, assessing and addressing the emotional needs and the psycho-social impact of social services users as well as ensuring access to psycho-social support and counselling.

\section{References}

Abrams, Laura S. and Alan J. Dettlaff. 2020. "Voices from the Frontlines: Social Workers Confront the COVID-19 Pandemic." Social Work 65 (3): 302305. https:// doi.org/10.1093/sw/swaa030.

ANDPDCA. 2020. “Ghid pentru angajații din serviciile sociale în contextul noului coronavirus" [Guidance for social service workers in the context of the new coronavirus]. Accessed November 27, 2020. http://andpdca.gov.ro/w/wp-content/uploads/2020/03/How-toprotect-frontline-workers_RO-final.pdf. 
C. Bacter, S. Săveanu, and C. Marc - Social work during the COVID-19 pandemic ...

Bacter, Claudia and Cristiana Marc. 2017. "Job Satisfaction among Social Workers. A Study in Bihor County." Revista de Asistență Socială 1: 6574.

Banerjee, Debanjan. 2020. "The impact of Covid-19 pandemic on elderly mental health." International Journal Geriatric Psychiatry 35(12): 14661467. https:// doi.org/10.1002/gps.5320.

Banks, Sarah, Tian Cai, Ed de Jonge, Jane Shears, Michelle Shum, Ana M. Sobočan, Kim Strom et al. 2020a. "Ethical challenges for social workers during Covid-19: A global perspective" Rheinfelden, Switzerland: International Federation of Social Workers. Accessed December 2, 2020. https://www.ifsw.org/ethical-challenges-for-social-workersduring-covid-19-a-global-perspective/.

Banks, Sarah, Tian Cai, Ed de Jonge, Jane Shears, Michelle Shum, Ana M. Sobočan, Kim Strom et al. 2020b. "Practicing ethically during COVID19: Social work challenges and responses." International Social Work 63(5): 569-583. https:// doi.org/10.1177/0020872820949614.

Boddy, Jwnnifwe and Lena Dominelli. 2017. "Social Media and Social Work: The Challenges of a New Ethical Space." Australian Social Work 70(2): 172-184. https:// doi.org/10.1080/0312407X.2016.1224907.

Cole, Charles Lewis, S. Waterman, J. Stott, Rob Saunders, J.E.J. Buckman, S. Pilling and J. Wheatley. 2020. "Adapting IAPT services to support frontline NHS staff during the Covid-19 pandemic: the Homerton Covid Psychological Support (HCPS) pathway." Cognitive behaviour therapist 13(e12). https:// doi.org/10.1017/S1754470X20000148.

Cook, Laura L. and Danny Zschomler. 2020. "Child and family social work in the context of COVID-19: practice issues and innovations" Briefing Paper. Norwich: CRCF. Accessed December 3, 2020. http://www.uea.ac.uk/crcf.

Decision no. 24 of 14 May 2020 regarding the approval of the establishment of the state of alert at national level and the measures for prevention and control of infections, in the context of the epidemiological situation generated by SARS-COV-2 virus.

Decree of the President of Romania no. 195 of 16 March 2020 regarding the establishment of the state of emergency on the territory of Romania, published in the OM of Romania no. 212 of 16 March 2020.

Decree of the President of Romania no. 240 of 14 April 2020 regarding the extension of the state of emergency on the Romanian territory, published in the OM of Romania no. 311 of 14 April 2020. 
Dominelli, Lena. 2021. "A green social work perspective on social work during the time of COVID-19." International Journal of Social Welfare 30(1): 7-16. https://doi.org/10.1111/ijsw.12469.

Dominelli, Lena., Timo Harrikari, Joseph Mooney, Vesna Leskošek and Erin Kennedy Tsunoda. 2020. "COVID-19 and Social Work: A collection of country reports" Contributors are members of the COVID-19 Social Work Research Forum. Accessed December 15, 2020 https://www.iassw-aiets.org/wpcontent/uploads/2020/07/IASSW-COVID-19-and-Social-WorkCountry-Reports-Final-1.pdf.

Farkas, Kathleen J. and J. Richard Romaniuk. 2020. "Social work, ethics and vulnerable groups in the time of coronavirus and Covid-19." Society Register 4(2): 67-82. https:/ / doi.org/10.14746/sr.2020.4.2.05.

Golightley, Malcolm and Margaret Holloway. 2020. "Social Work in the Time of the COVID-19 Pandemic: All in This Together?." The British Journal of Social Work 50(3): 637-641. https://doi.org/10.1093/bjsw/bcaa036.

Holliday, Stephanie Brooks, Sarah B. Hunter, Alex R. Dopp, Margaret Chamberlin and Martin Y. Iguchi. 2020. "Exploring de impact of COVID-19 on Social Services for Vulnerable Populations in Los Angeles. Lessons Learned from Community Providers", RAND Social and Economic Well-Being Corporation, Santa Monica, California; CA: RAND Corporation. Accessed December 15, 2020. https://www.rand.org/pubs/research_reports/RRA431-1.html.

Inchausti, Felix, Angus MacBeth, Ilanit Hasson-Ohayon and Giancarlo Dimaggio. 2020. "Psychological Intervention and COVID-19: What We Know So Far and What We Can Do." Journal of contemporary psychotherapy 50: 243-250. https:/ / doi.org/10.1007/s10879-020-09460w.

Lazăr Florin, Liliana Roșu, Diana Cristea and Mihai Bogdan Iovu. 2020. "Perspective asupra sistemului și serviciilor de asistență socială din România" [Perspectives on the social work services system in Romania], București: Editura Tritonic.

Lazăr, Florin, Anca Mihai, Daniela Gaba, Alexandra Ciocănel, Georgiana Rentea and Shari Munch. 2019 "Romanian social workers facing the challenges of neo-liberalism." European Journal of Social Work 22(2): 326-337. https:/ / doi.org/10.1080/13691457.2018.1540405.

Lazăr, Florin, Csaba Laszlo Dégi and Mihai Bogdan Iovu. 2016. "Renașterea unei profesii sau despre cum este să fii asistent social în România" [Rebirth of a profession or on what it's like to be a social worker in Romania] București: Editura Tritonic. 
Lazăr, Florin. 2015. "Profilul asistenților sociali din România" [The profile of social workers in Romania], CNASR, Timișoara: Editura de Vest.

Marc, Cristiana and Claudia Oşvat. 2013. "Stress and Burnout Among Social Workers." Revista de Asistență Socială 3: 113-124.

Mishna, Faye, Elizabeth Milne, Marion Bogo andLuana F. Pereira. 2020. "Responding to COVID-19: New Trends in Social Workers' Use of Information and Communication Technology." Clinical Social Work Journal, Open Access https://doi.org/10.1007/s10615-020-00780-x.

Ministry of Labor and Social Protection. 2020. "Recomandări privind prevenirea și managementul situației generate de Pandemia de COVID-19 în serviciile sociale" [Recommendations on the prevention and management of the situation generated by the COVID-19 pandemic in social services]. Accessed December 18, 2020. http://www.mmuncii.ro/j33/images/Documente/MMPS/Servicii_ Sociale/MMPS-DPSS-COVID19_Recomandari_prevenireamanagementul-sit-genrate-de-pandemie.pdf.

Ministry of Labor and Social Protection - ANPDCA. 2020. "Dispoziție metodologică nr. 6377 din 9.03.2020". Accessed December 18, 2020. http://andpdca.gov.ro/w/wpcontent/uploads/2020/03/Dispozitie-metodologica.pdf.

Military Ordinance no. 8 of April 9, 2020 on measures to prevent the spread of COVID-19, published in the OM of Romania no. 301 of April 10, 2020.

National College of Social Workers in Romania. 2020. "Recomandări pentru asistenții sociali care lucrează în servicii publice de asistență social" [Recommendations for social workers working in public social assistance services]. Accessed December 18, 2020. https://main.components.ro/uploads/12c6a09675620f589055800ba6 ceceee/2020/03/recomand-ri-pentru-asisten-ii-sociali-care-lucreaz-nservicii-publice-de-asistenta-sociala.pdf.

Quality of Life Research Institute. 2020. "Pandemia și standardul de viață. Politici de protecție social" [Pandemic and standard of living. Social protection policies], București: Institutul de Cercetare a Calității Vieții. Accessed December 7, 2020. http://www.iccv.ro/wpcontent/uploads/2020/04/Raport-social-ICCV-aprilie-2020.pdf.

Redondo-Sama, Gisela, Virginia Matulic, Ariadna Munté-Pascual and Irene de Vicente. 2020. "Social Work during the COVID-19 Crisis: Responding to Urgent Social Needs." Sustainability 12(20): 1-16. https://doi.org/10.3390/su12208595 . 
Runcan, Remus. 2020. "Sociology and healthcare Social work in Romania in the time of the Covid-19 Pandemic: strengths and weaknesses." In NORDSCI International Conference on Social Sciences, Sociology and Health Care, 273-279. Sofia: Saima Consult LTD.

Sukmana, Oman and Zaenal Abidin. 2020. "The Role of Social Workers in Social Work Practices by Using Information Technology during the Covid-19 Pandemic: Study in East Java Province, Indonesia" International Journal of Advanced Science and Technology 29(8): 13161325.

UNICEF. 2020. "Social service workforce safety and wellbeing during the covid-19 response. Recommended actions". Accessed December 21, 2020. https://www.unicef.org/media/68501/file/Social-ServiceWorkforce-Safety-and-Wellbeing-during-COVID19-Response.pdf.

UNICEF Romania. 2020. “Evaluarea rapidă a situației copiilor şi familiilor , cu accent pe categoriile vulnerabile, în contextul epidemiei de COVID19 din România" [Rapid assessment of the situation of children and families, with a focus on vulnerable categories, in the context of the COVID-19 epidemic in Romania]. Accessed December 22, 2020. https://www.unicef.org/romania/media/2221/file/EVALUAREA \%20RAPID\%C4\%82\%20A\%20SITUA \%C8\%9AIEI\%20COPIILOR $\% 20$ \%C5\%9EI\%20FAMILIILOR,\%20CU\%20ACCENT\%20PE\%20CATEG ORIILE\%20VULNERABILE, $\% 20 \%$ C3\%8EN\%20CONTEXTUL\%20EPI DEMIEI\%20DE\%20COVID-19\%20DIN\%20ROM\%C3\%82NIA.pdf.

Walter-McCabe, Heather A. 2020. "Coronavirus Pandemic Calls for an Immediate Social Work Response." Social Work in Public Health 35(3): 69-72. https:// doi.org/10.1080/19371918.2020.1751533. 


\section{Appendix}

Table 2. Type of change of procedures (open-ended question; the number in parentheses specifies the number of answers by category):

more online activities or by phone (28)

protection measures, hygiene, social distance (antiCovid-19 measures) (18)

relationship and communication with beneficiaries, limited contacts (17)

increased amount of work, more documents, reports (10)

change of schedule, working time (10)

isolation conditions (at work or at home) (9)

reduced nobilities, less filed work (5)

limited number of people participating in joint activities, increased

individual activities (3)

limitation / canceled some services offered to the beneficiaries (2)

relationship and communication with partners, collaborators (2)

stress, emotional load (2)

increased time spent with beneficiaries (1)

Table 3. Type of change in the relationship with beneficiaries (open question; the number in parentheses specifies the number of answers by category):

contact by phone, support offered on the phone or online (21)

less direct contact, less interactions, less field work (15)

closer relationship, trying to spending more time toghether (4)

moved online, less direct contact, less social and emotional impact (4)

they are more scared, more vulnerable, need more councelling (3)

closer relationship (2)

beneficiaries lose their patience (1)

cant' give them all the support needed (1)

less participation in activities (1)

more appreciation of our job (1)

more distant pacients (1)

more focus on problem solving (1)

shorter meetings (1)

their needs are more complex (1)

they need to be more involved (1)

they are more open (1)

Table 4. Type of change in the relationship with collaborators (open question; the number in parentheses specifies the number of answers by category):

The collaboration continued by phone or online (22) 
Difficult collaboration (phone or e-mail) or interrupted (18)

Postpone or cancel some activities, Collaborators canceled their activities (6)

Collaboration has improved (5)

Limited contact, less communication, less interactions (5)

Less filed work (1)

Less willing for partnerships (1)

Longer time for intervention (1)

Working from home (1)

Table 5. Negative and positive aspects during pandemic

Negative aspects in this period (open question; the number in parentheses specifies the number of answers by category):

isolation, social distancing (14)

lack of direct contact with beneficiaries and colleagues (14)

stress, mental tension, care for myself and others, anxiety (7)

uncertainty about the rules, not getting prompt information, lack of

communication, pressure from management (7)

uncertainty when we return, not knowing the conditions, uncertainty

about the job (6)

uncertainty (4)

cancel of some activities (3)

lack of freedom (3)

great amount of work when we return (2)

lack of human resources (2)

physical and mental tiredness (2)

protection clothing, sanitation measures (2)

salary loss (2)

technical unemployment (2)

work program (2)

difficult collaboration with institutions (1)

lack of protection equipment (1)

misinformation (1)

more responsibilities (1)

unpaid work (1)

will of getting back to work (1)

Positive aspects in this period (open question; the number in parentheses specifies the number of answers by category): 


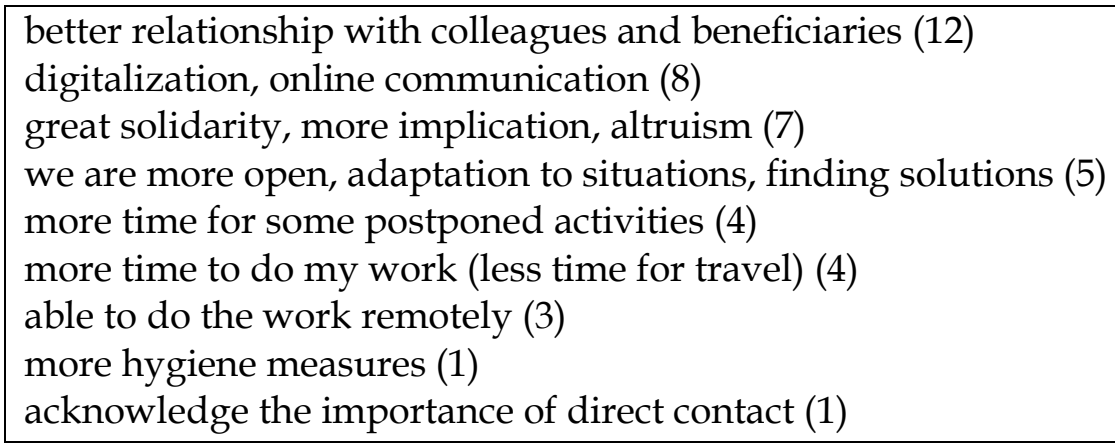

Table 6. Changes needed at the working place (open-ended question; the number in parentheses specifies the number of answers by category):

better hygiene measures, protective equipment, greater implication of authorities in providing these resources (11)

going back to (normal) work (9)

greater implication and collaboration, greater involvement,

responsiveness to suggestions on how to work with beneficiaries,

openness to new methods of intervention (9)

better communication (8)

flexibility at work and working schedule (8)

better collaboration with colleagues (7)

better payment, equal payment for equal work (6)

greater interest and understanding from management; a change of vision and understanding at the level of management (5)

direct contact with beneficiaries, face-to-face communication (3)

Table 7. Measures to be kept in the future (open-ended question; the number in parentheses specifies the number of answers by category): What would you keep from the measures / activities introduced during this period?

hygiene measures, health protection measures (18)

rapid transfer of information, transmission of documents online between services or institutions, online communication, use of modern communication techniques, working online, online collaboration (16)

work from home occasionally (for some tasks); flexible work schedule with the possibility of working from home (7)

Nothing (26) 